\title{
Assessment of Microbiological Quality and Mycotoxin in Dried Chili by Morphological Identification, Molecular Detection, and Chromatography Analysis
}

\author{
Rachma Wikandari ${ }^{1}$, Inggrid Chrisanti Mayningsih ${ }^{1}$, Maura Dania Permata Sari ${ }^{1}$, \\ Fiametta Ayu Purwandari ${ }^{1}$, Widiastuti Setyaningsih ${ }^{1}{ }^{\circledR}$, Endang Sutriswati Rahayu ${ }^{1}$ and \\ Mohammad J. Taherzadeh $2, *$ (D) \\ 1 Department of Food and Agricultural Product Technology, Gadjah Mada University, Yogyakarta 55281, \\ Indonesia; Rachma_wikandari@mail.ugm.ac.id (R.W.); inggridchrisanti@gmail.com (I.C.M.); \\ Mauradaniaps@gmail.com (M.D.P.S.); fiametta@ugm.ac.id (F.A.P.); \\ widiastuti.setyaningsih@ugm.ac.id (W.S.); endangsrahayu@ugm.ac.id (E.S.R.) \\ 2 Swedish Centre for Resource Recovery, University of Borås, 50190 Borås, Sweden \\ * Correspondence: mohammad.taherzadeh@hb.se; Tel.: +46-334-355-908
}

Received: 7 February 2020; Accepted: 10 March 2020; Published: 12 March 2020

\begin{abstract}
The growing interest in spicy foods leads to the global demand for spices, particularly dried chili. This study aimed to assay both aflatoxin (AFs) and ochratoxin A (OTA) contamination using an integrative method of morphological identification, molecular detection, and chromatography analysis on dried chili provided from traditional and modern markets in Indonesia. The results showed that total fungal infection ranged from 1-408 $\times 10^{3} \mathrm{CFU} / \mathrm{g}$. Eighty percent of the chili obtained from both the traditional and the modern markets were infected by Aspergillus spp., in which $50 \%$ of the infections were identified as A. parasiticus and A. flavus. A complete set of targeted genes involved in AF production and OTA were detected in two isolates of $A$. flavus and one isolate of $A$. carbonarius, respectively. The levels of $A F s B_{1}, B_{2}$, and OTA in the contaminated dried chilies were in the range of $39.3-139.5 \mu \mathrm{g} / \mathrm{kg}, 2.6-33.3 \mu \mathrm{g} / \mathrm{kg}$, and 23.7-84.6 $\mu \mathrm{g} / \mathrm{kg}$, respectively. In contrast, no AFs $\mathrm{G}_{1}$ and $\mathrm{G}_{2}$ were detected. This study showed that the fungal infection of Indonesian dried chili occurs both in the field and during storage; thus, it is suggested to implement good agricultural and handling processes.
\end{abstract}

Keywords: aflatoxin; ochratoxin A; dried chili; Indonesia; molecular; mycobiota

\section{Introduction}

Spicy food has been gaining global attention, and this has promoted an increase of demand for spices in the market, notably chili. Chili is a fruit of the Capsicum plant belonging to the Solanaceae genus, which is originated from America. Chili is an essential ingredient which is added to main dishes or sauces worldwide. Besides its culinary application, there has been growing interest in utilizing chili for medical purposes such as in pain killers and anticancer agents. Chili is available in the market in the form of fresh and dried products. There are several types of dried chili, such as whole chili, in flakes, and in ground powder. China is the main supplier of dried whole and ground chili in the European market [1]. However, according to a report from the Rapid Alert System for Food and Feed (RASFF), approximately $36 \%$ of the alerts in the last fifteen years for dried chili from China are due to mycotoxin contamination [2].

Mycotoxins are the secondary metabolites produced by fungi that have detrimental effects on human and animal health. Among the 400 known mycotoxins, aflatoxin (AFs) and ochratoxin (OTA) 
pose the primary concern to animal and human health. AFs are mainly produced by Aspergillus flavus and Aspergillus parasiticus and are the most potent natural carcinogenic found in nature. AFs pose several toxic effects in animals and humans, such as carcinogenic, mutagenic, teratogenic, and immunosuppressive activity [3]. The most common $A F s$ present in food are $B_{1}, B_{2}, G_{1}$, and $G_{2}$. $A F B_{1}$ has the highest genotoxic and carcinogenic effect, as well as being the most commonly found AF in agricultural products [4]. $\mathrm{AFB}_{1}$ and $\mathrm{AFs}$ have been classified as group I carcinogens (carcinogenic to humans) by the International Agency for Research on Cancer (IARC) [5]. OTA, which is produced by Penicillium verrucosum, A. ochraceus, and A. niger [6], is reported to cause chronic kidney disease and may be associated with the development of gallbladder cancer [7]. Similar to AFs, the toxic effects of OTA against various experimental animals include carcinogenic, teratogenic, immunotoxic, genotoxic, and possibly neurotoxic activity [8]. According to IARC, OTA has been classified as a group $2 \mathrm{~B}$ carcinogen based on sufficient evidence for carcinogenicity in animal studies and inadequate evidence in humans [5].

Mycotoxin can be produced in a crop during pre and post-harvest. Several factors influence mycotoxin production during pre-harvest, including the type of soil and crop as well as the amount of Aspergillus contaminating the plant [9]. Besides this, the higher temperature, humidity, and heavy rainfall result in a higher risk of mycotoxin contamination [9]. Similarly, higher temperature and humidity during storage also increase the risk of AF production post-harvest [9]. Hence, crops of tropical countries are more prone to AF contamination due to their climate, with high temperatures and moisture, monsoons, unseasonal rains during harvest, and flash floods [10].

Several studies have reported mycotoxin contamination in chilis from Turkey, Pakistan, Malaysia, Bangladesh, Qatar, and Saudi Arabia [11-16]. However, most of these studies only assessed the mycotoxin level, and few studies estimated the fungal contamination or molecular tool for the detection of toxigenic fungi. Additionally, another report showed OTA contamination; the rest only focus on AFs [13]. To the best of our knowledge, a combination of morphological identification, molecular tools, and the chromatographic technique for the identification and quantification of both AFs and OTA in contaminated foods has never been reported. The integration of these approaches is particularly important to give a better insight into recognizing the potential risk for both AF and OTA contamination.

In this study, therefore, we used integrative approaches consisting of morphological, molecular, and chromatography techniques to assay both AF and OTA contamination in dried chili marketed in Indonesia. Indonesia is a tropical country, with a climate which is susceptible to mold growth and mycotoxin production. Although Indonesia is the largest chili producer in Southeast Asia and the fourth largest in the world, contributing 5.8\% of global production [17], mycotoxin contamination in Indonesian dried chili has not yet been reported. Our samples were taken from two different types of markets-i.e., traditional and modern markets—to study the effect of sanitation on the microbiological quality of the dried chili.

\section{Materials and Methods}

\subsection{Materials}

The dried chilies used in this study were purchased randomly from both the traditional and the modern markets in the form of whole, ground, and powdered samples. The cultivars of chili samples provided from the traditional markets were green cayenne chili, white bird's eye chili, red pepper, red bird's eye chili, and red cayenne chili. Six samples from the traditional markets were in the form of dried chili, and two samples were in the form of powdered chili. The samples taken from the modern market included six powdered chilies and one dried chili from different brands. The samples were stored at $4{ }^{\circ} \mathrm{C}$ after purchase. 


\subsection{Chemicals and Reagents}

All chemicals were of analytical reagent grade, except for methanol and acetonitrile, which were of high-performance liquid chromatography (HPLC) grade. All the chemicals were purchased from Merck (Darmstadt, Germany). All solutions were prepared using de-ionized water. AFs and OTA standards were purchased from Trilogy Analytical Laboratory (Washington, Missouri). Each standard of AFs contained $5 \mu \mathrm{g} / \mathrm{mL}$ of AFB1, AFB2, AFG1, AFG2, and the concentration of OTA was $1 \mu \mathrm{g} / \mathrm{mL}$.

\subsection{Fungal Occurrence in Chilis}

To investigate the fungal occurrence in the dried chili, $10 \mathrm{~g}$ of each sample was mixed with $90 \mathrm{~mL}$ of sterile $\mathrm{NaCl} 0.85 \%$. Each mixture was shaken vigorously. The fungus culture method was based on Rahayu et al. [18]. The samples were diluted by a factor of 10, 100, and 1000. Subsequently, $0.1 \mathrm{~mL}$ of the mixture for each dilution was aseptically inoculated onto a Dichloran-18 Glycerol (DG-18) (Oxoid Ltd., Hants, UK) agar plate with $0.01 \%$ chloramphenicol (Merck, Darmstadt, Germany). The plates were then incubated at $25^{\circ} \mathrm{C}$ for 5-7 days. After 2-3 days of incubation, the growing fungal colonies were counted, and at the end of incubation, the color of the colony was observed. The frequency of fungal occurrence was calculated as colony-forming units (CFU) per gram of samples.

\subsection{Isolation and Identification of Fungi from Dried Chili and Chili Powder}

Each formed colony with a green and black color in DG-18 agar was suspected as Aspergillus and thus transferred into Malt Extract Agar (MEA) (Oxoid Ltd., Hants, UK) with 0.01\% chloramphenicol (Merck, Darmstadt, Germany). The isolation of the molds was carried out based on the methods of Samson et al. [19]. For identification, each isolate was grown in MEA and Czapek Yeast Extract Agar (Merck, Darmstadt, Germany) medium with $0.01 \%$ chloramphenicol (Merck, Darmstadt, Germany). The isolates were identified based on their micro and macromorphology [18,20,21].

\subsection{Molecular Identification of AF and OTA-Producing Isolates}

Fungal DNA was extracted using an Invisorb ${ }^{\circledR}$ Spin Plant Mini Kit (Stratec Molecular Gmbh, Berlin, Germany). The DNA was then amplified using PCR with the primers nor-1, aflR, and omtB to screen for the AF biosynthesis gene. To screen for the OTA biosynthesis gene, the polyketide gene was amplified using the primers AcPKS and AnPKS. All primers were ordered from Integrated DNA Technologies (IDT, Coralville, Iowa). The sequence of the primers used for amplification is shown in Table 1. The reaction of PCR amplification was performed in $25 \mu \mathrm{L}$ of mix PCR (GoTaq ${ }^{\circledR}$ Master Mixes, Promega, Madison, USA) mixed with $21 \mu \mathrm{L}$ distilled water, $1 \mu \mathrm{L}$ of each primer, and $1 \mu \mathrm{L}$ of DNA template. The PCR program is presented in Table 2.

Table 1. Sequence of primers used for PCR analysis [22-24].

\begin{tabular}{ccc}
\hline Genes & Forward Primer $\mathbf{5}^{\prime} \mathbf{- 3}^{\prime}$ & ${\text { Reverse Primer } \mathbf{5}^{\prime} \mathbf{- 3}^{\prime}}^{\prime}$ \\
\hline AflR & CGCGCTCCCAGTCCCCTTGATT & CTTGTTCCCGATGACCA \\
Nor-1 & ACCGCTCCGGCACTCTCGGCA & GTTGGCCGCCAGCTTCGACACAGC \\
OmtB & GCCTTGACATGGAAACCATC & CCAAGATGGCCTGCTCTTTA \\
$A c P K S$ & GCAGCGGGAGTCAATGTAAT & GCGTCGTACAAAGCCTCTT \\
AnPKS & ACGGTAAACGTCCTGGATGA & CGTGCTGTTGAAGCCACTT \\
\hline
\end{tabular}

Table 2. Program of Polymerase Chain Reaction for amplification of genes involved in aflatoxin (AF) and ochratoxin A (OTA) production.

\begin{tabular}{cccccc}
\hline Genes & Cycle & Denaturation & Annealing & Extension & Final Extension \\
\hline$a f l R$ & 35 & $94^{\circ} \mathrm{C}, 60 \mathrm{~s}$ & $62^{\circ} \mathrm{C}, 60 \mathrm{~s}$ & $72{ }^{\circ} \mathrm{C}, 120 \mathrm{~s}$ & $72{ }^{\circ} \mathrm{C}, 600 \mathrm{~s}$ \\
$n o r-1$ & 30 & $95^{\circ} \mathrm{C}, 60 \mathrm{~s}$ & $65^{\circ} \mathrm{C}, 120 \mathrm{~s}$ & $72{ }^{\circ} \mathrm{C}, 240 \mathrm{~s}$ & $72{ }^{\circ} \mathrm{C}, 600 \mathrm{~s}$ \\
omtB & 35 & $94^{\circ} \mathrm{C}, 60 \mathrm{~s}$ & $55^{\circ} \mathrm{C}, 60 \mathrm{~s}$ & $72{ }^{\circ} \mathrm{C}, 60 \mathrm{~s}$ & $72{ }^{\circ} \mathrm{C}, 600 \mathrm{~s}$ \\
AnPKS & 35 & $95^{\circ} \mathrm{C}, 10 \mathrm{~s}$ & $52^{\circ} \mathrm{C}, 10 \mathrm{~s}$ & $72{ }^{\circ} \mathrm{C}, 15 \mathrm{~s}$ & $72{ }^{\circ} \mathrm{C}, 300 \mathrm{~s}$ \\
AcPKS & 35 & $95^{\circ} \mathrm{C}, 10 \mathrm{~s}$ & $62^{\circ} \mathrm{C}, 10 \mathrm{~s}$ & $72{ }^{\circ} \mathrm{C}, 15 \mathrm{~s}$ & $72{ }^{\circ} \mathrm{C}, 300 \mathrm{~s}$ \\
\hline
\end{tabular}




\subsection{Mycotoxin Extraction from Dried Chili}

The whole chili samples were first grounded. For AF extraction, ground chili $(25 \mathrm{~g})$ was blended with $125 \mathrm{~mL}$ of methanol/water $(80 / 20 \mathrm{v} / \mathrm{v})$ and $2.5 \mathrm{~g} \mathrm{NaCl}$ for $30 \mathrm{~min}$. The mixture was then incubated in a shaker for $1 \mathrm{~h}$. Subsequently, $125 \mathrm{~mL}$ of distilled water was added to the mixture, and the mixture was filtrated through a filter paper (Whatman grade 4, Whatman International Ltd., Maidstone, UK). The filtrate $(10 \mathrm{~mL})$ was diluted with $20 \mathrm{~mL}$ of phosphate-buffered saline (PBS), and the $\mathrm{pH}$ was adjusted to 7.2 using $2 \mathrm{M} \mathrm{NaOH}$. For purification, the diluted filtrate $(10 \mathrm{~mL})$ was then subjected through an immunoaffinity column (IAC) (Aflaprep PO7, R-Biopharm RhÔne Ltd., Glasgow, UK) at a flow rate of $2 \mathrm{~mL}$ per minute. To remove undesired compounds, $20 \mathrm{~mL}$ of PBS was passed through the IAC at $5 \mathrm{~mL} / \mathrm{min}$. To elute the AFs, $500 \mu \mathrm{L}$ of methanol and water $(80 / 20 \mathrm{v} / \mathrm{v})$ was slowly passed through the column. The elute was collected in a tube, and this process was repeated until $1 \mathrm{~mL}$ of elute was obtained. The methanol was then evaporated using nitrogen until the dry sample was obtained. Subsequently, the sample was reconstituted in $20 \mu \mathrm{L}$ of mobile phase. For OTA extraction, ground samples (12.5 g) were mixed with $100 \mathrm{~mL}$ of $\mathrm{NaHCO}_{3} 1 \%$ and incubated in a shaker for $1 \mathrm{~h}$. The mixture was centrifuged at $3500 \mathrm{rpm}$ for $10 \mathrm{~min}$, and the mixture was filtrated through a filter paper (Whatman grade 4 , Whatman International Ltd., Maidstone, UK). PBS ( $8 \mathrm{~mL}$ ) was then added to the filtrate and homogenized. The $\mathrm{pH}$ was adjusted to 7.2 by $2 \mathrm{M} \mathrm{NaOH}$, and the mixture was passed through an immune affinity column (Ocraprep, PO7, R-Biopharm RhÔne Ltd., Glasgow, UK). PBS (20 mL) with a pH of 7.2 was slowly passed through the IAC to remove undesired compounds. Subsequently, $1.5 \mathrm{~mL}$ of $\mathrm{MeOH}$ : glacial acetic acid (98:2) was added to the column and incubated for $5 \mathrm{~min}$. The samples were dried with nitrogen to remove the methanol. The sample was then reconstituted in $400 \mu \mathrm{L}$ of mobile phase and subjected to analysis by HPLC.

\subsection{Mycotoxin Determination by HPLC}

The AF and OTA concentrations were analyzed by high-performance liquid chromatography (HPLC) (Shimadzu LC-20 AD, Kyoto, Japan) using a C18-analytical column (LiChrosphere 100 RP-C18e, Merck, Darmstadt, Germany) and fluorescence detector. An isocratic mobile phase for AF analysis was methanol/water (40:60 v/v) adjusted with $350 \mu \mathrm{L}$ of $4 \mathrm{M}$ nitric acid and $119 \mathrm{mg}$ of $\mathrm{HNO}_{3}$ and $119 \mathrm{mg}$ $\mathrm{KBr}$ per $1 \mathrm{~L}$ of mobile phase. The mobile phase for OTA analysis was acetonitrile/distilled water/glacial acetic acid $(45: 52.5: 25 \mathrm{v} / \mathrm{v})$. A sample $(20 \mu \mathrm{L})$ was injected into the HPLC system with a flow rate of $1 \mathrm{~mL} / \mathrm{min}$. The fluorescence detector was set with excitation and emission wavelengths of the detector of 350 and $450 \mathrm{~nm}$, respectively, for AF analysis. In contrast, for OTA analysis, they were set at $336 \mathrm{~nm}$ and $440 \mathrm{~nm}$, respectively. The analytical column temperature was maintained at $40^{\circ} \mathrm{C}$ for both $\mathrm{AF}$ and OTA analysis. The samples were injected into an HPLC column and then subjected to post-column derivatization (Kobra Cell, R-Biopharm Rhône Ltd., Glasgow, UK). The limits of detection (LODs) were $0.61 \mu \mathrm{g} / \mathrm{kg}$ for $\mathrm{AFB}_{1}, 0.05 \mu \mathrm{g} / \mathrm{kg}$ for $\mathrm{AFB}_{2}, 0.553 \mu \mathrm{g} / \mathrm{kg}$ for $\mathrm{AFG}_{1}, 0.06 \mu \mathrm{g} / \mathrm{kg}$ for $\mathrm{AFG}_{2}$ and $0.53 \mu \mathrm{g} / \mathrm{kg}$ for OTA. The standard curve was linear at six concentrations between 12.5 and $400 \mathrm{ng} / \mathrm{mL}$. The $R^{2}$ values for AFs G2, G1, B2, and B1 were 0.996, 0.997, 0.996, and 0.996, respectively.

\subsection{Experimental Design and Data Analysis}

A non-factorial experiment was conducted to evaluate the fungal contamination of dried chili purchased from traditional and modern markets. The single factor ANOVA was calculated to determine the effect of different markets on the contamination $(p<0.05)$.

\section{Results}

\subsection{Microbiota of Dried and Powdered Chili}

The microbiota of dried chili cultivated in DG-18 agar plates are presented in Figure 1. The fungal contamination levels of the chilies ranged from 1 to $408 \times 10^{3} \mathrm{CFU} / \mathrm{g}$. The level of fungal contamination in this study did not exceed the range reported in previous studies. In Saudi Arabia, 
total counts of fungi isolated from red pepper were 1.8-1.5 $\times 10^{3} \mathrm{CFU} / \mathrm{g}$ [25]. In Spain, fungal counts were between $<0.1 \times 10^{3}$ and $46 \times 10^{3} \mathrm{CFU} / \mathrm{g}$ in Capsicum powder [26]. In Iran, mold and yeast contamination was between $24 \times 10^{3}$ and $4600 \times 10^{3} \mathrm{CFU} / \mathrm{g}$ in Iranian red pepper spice [27]. In Korea, fungal contamination in ground red pepper was $7.3 \times 10^{3} \mathrm{CFU} / \mathrm{g}$ [28]. The contamination level for the traditional market on average $\left(142 \times 10^{3} \mathrm{CFU} / \mathrm{g}\right)$ was not significantly different from that purchased from the modern market $\left(87 \times 10^{3} \mathrm{CFU} / \mathrm{g}\right)$. In addition, the microbiota of chili purchased from the traditional market was more diverse than in the modern market. Dried chili purchased from the traditional market was contaminated with five genera (Penicillium spp., Eurotium spp., Fusarium spp., Mucor spp. and Aspergillus spp.); meanwhile, only three genera (Penicillium spp., Eurotium spp. and Aspergillus spp.) were detected in dried chili purchased in the modern market. The results of this work were in agreement with a previous study reporting that Aspergillus, Penicillium, and Fusarium are commonly isolated fungi from red pepper [25].

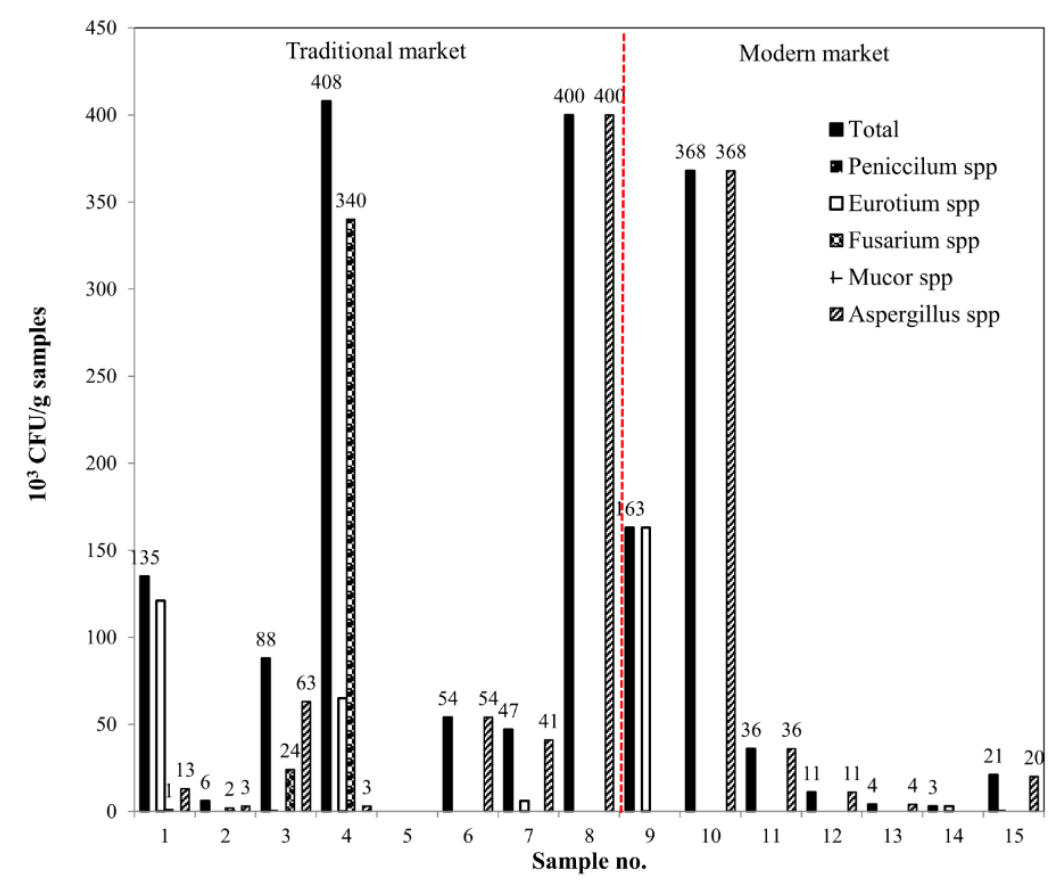

Figure 1. Microbiota of dried and powdered chili from the traditional and the modern market.

The frequencies of contamination of each genus, excluding Penicillium spp., were higher in dried chili from the traditional market than the modern market (Figure 2). For instance, the percentages of contaminated dried chilies by Eurotium spp. and Aspergillus spp. were 37.5\% and 87.5\%, respectively, in the traditional market compared to $28.17 \%$ and $71.43 \%$ in the modern market, respectively The higher amount of microbiota diversity and occurrence frequency of the fungal contamination in the traditional market compared to the modern market could be explained by the lower sanitary and quality standards applied to dried chili in the traditional market. The result of the current study showed that both storage molds and field fungi were found in samples purchased from the traditional market, which indicates that the contamination of the products may occur both in the field and/or during storage. One explanation for this could be that the buildings of the traditional market are often semi-open-air, without a partition between each seller for different commodities, thus allowing street dust and cross-contamination to occur during the display of the products. In addition, sun-drying is the most common practice for drying the chili in the traditional market; thus, the risk of contamination from soil and air increases. In contrast, the contamination in chili purchased from the modern market might only occur during storage, as no Fusarium spp. was detected. 


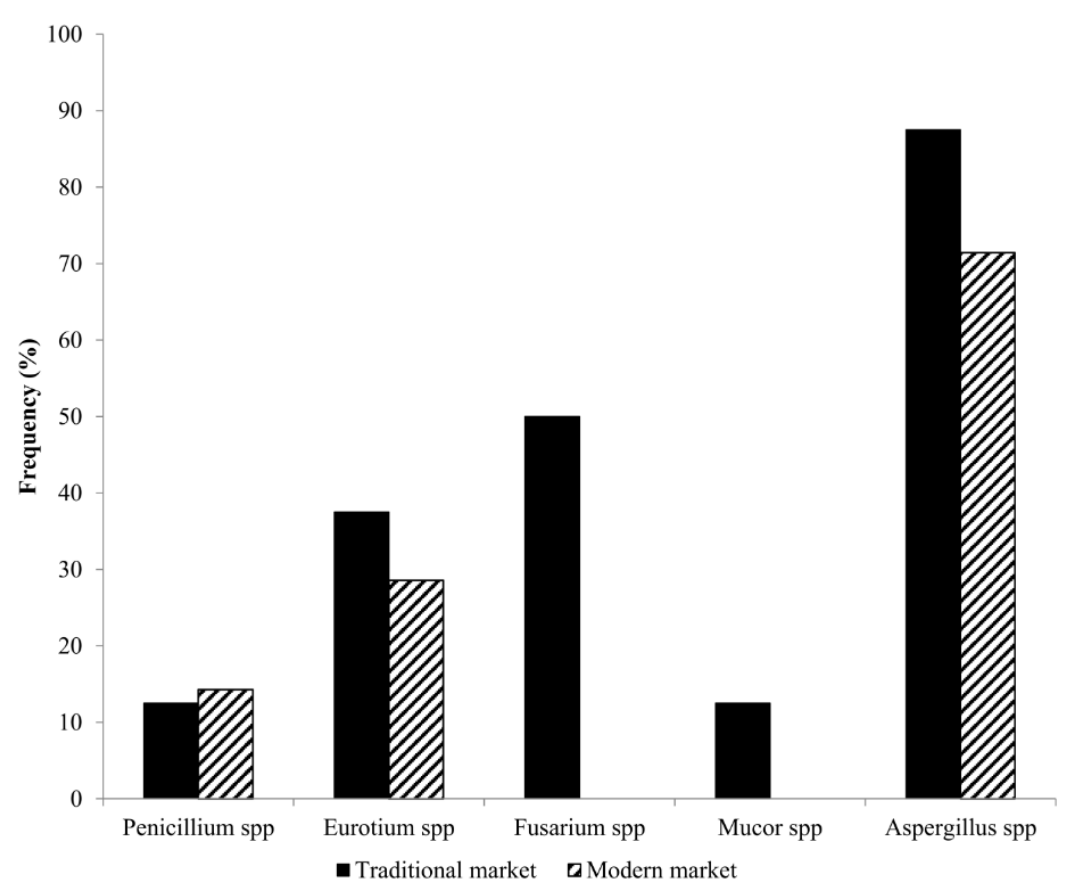

Figure 2. Frequency of fungal genera detected in dried and powdered chili from the traditional and the modern market.

\subsection{Identification of Aspergillus Spp. Fungi on Dried Chili and Chili Powder}

In general, $80 \%$ of the samples were contaminated by Aspergillus spp. The contaminations by these fungi were in the range of 3-400 $\times 10^{3} \mathrm{CFU} / \mathrm{g}$ in the traditional market and $4-368 \times 10^{3} \mathrm{CFU} / \mathrm{g}$ in the modern market. The isolates identified as Aspergillus spp. cultivated in DG-18 agar were cultivated in MEA and CYA for further identification to the species level based on their micro and macromorphology. The result shows that the total number of isolates of Aspergillus spp. found in all samples was 26 (Table 3). The species of Aspergillus detected in the samples were A. flavus, A. parasiticus, A. carbonarius, A. niger, and $A$. japonicus. All of these species were detected in dried chili taken from the traditional market. However, $A$. niger was absent in the sample taken from the modern market. In general, the samples were dominated by A. flavus and A. parasiticus, followed by A. carbonarius, A. japonicus, and A. niger. Dried chili purchased from the traditional market was dominated by $A$. parasiticus, followed by A. carbonarius, and the rest were present in the same frequencies (Figure 3). Meanwhile, dried chili purchased from the modern market was dominated by A. flavus, followed by A. carbonarius, and others found in the same frequencies. This result is in accordance with a previous study [29] which reported that $A$. flavus and $A$. niger were the most dominant fungi in red chili imported from various countries. The species of Aspergillus detected in red pepper in Saudi Arabia were A. flavus, A. niger, A. ochraceus and A.fumigatus [25]. It has been reported that Aspergillus section nigri was dominant in the chili powder sample [26].

Table 3. The occurrence of Aspergillus spp. detected in dried and powdered chili from the traditional and the modern market.

\begin{tabular}{cccccc}
\hline No. & Form, Type of Market & A. flavus & A.parasiticus A.carbonarius & A. niger & A.japonicus \\
\hline 1 & Powder, traditional & 0 & 1 & 1 & 0 \\
2 & Powder, traditional & 0 & 1 & 0 & 1 \\
3 & Whole, traditional & 0 & 1 & 1 & 0 \\
4 & Whole, traditional & 0 & 1 & 0 & 0 \\
5 & Whole, traditional & 0 & 0 & 0 & 0 \\
6 & Whole, traditional & 0 & 1 & 1 & 0 \\
\hline
\end{tabular}


Table 3. Cont.

\begin{tabular}{ccccccc}
\hline No. & Form, Type of Market & A.flavus & A.parasiticus A.carbonarius & A. niger & A.japonicus \\
\hline 7 & Whole, traditional & 1 & 0 & 0 & 0 & 0 \\
8 & Whole, traditional & 0 & 1 & 0 & 0 & 1 \\
9 & Powder, modern & 0 & 0 & 0 & 0 & 0 \\
10 & Powder, modern & 1 & 0 & 1 & 0 & 0 \\
11 & Powder, modern & 1 & 1 & 0 & 0 & 1 \\
12 & Ground, modern & 0 & 0 & 1 & 0 & 0 \\
13 & Powder, modern & 1 & 0 & 1 & 0 & 1 \\
14 & Powder, modern & 0 & 0 & 0 & 0 & 0 \\
15 & Powder, modern & 4 & 1 & 0 & 0 & 0 \\
\hline Total & & 8 & 8 & 6 & 1 & 3 \\
Frequency $(\%), \mathrm{n}=26$ & & 30.77 & 30.77 & 23.08 & 3.85 & 11.54 \\
\hline
\end{tabular}
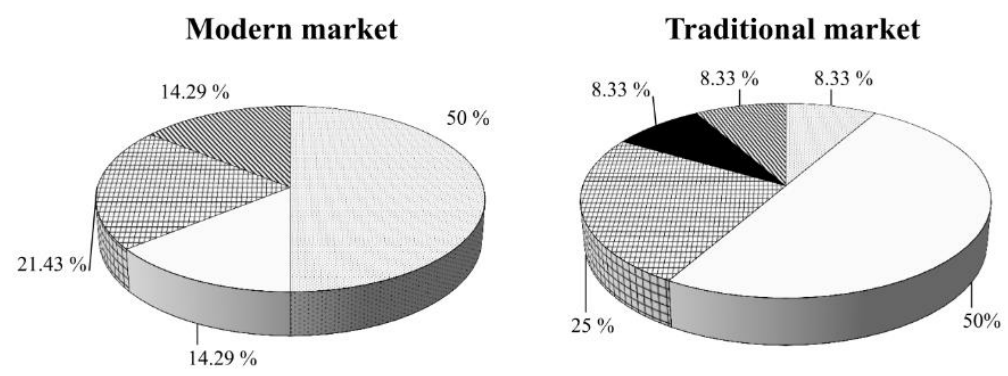

$\square$ A. flavus $\square$ A.parasiticus $\square$ A.carbonarius $\square$ A.niger $\mathbb{\otimes}$ A.japonicus

Figure 3. Frequency of Aspergillus spp. detected in dried and powdered chili from the traditional and the modern markets.

The high frequency (50\%) of A. parasiticus and A. flavus both in the traditional and the modern markets indicated the risk of mycotoxin contamination in the sample as A. flavus and A. parasiticus are commonly known as AF producers. In addition, $70 \%$ of the chili samples were infected by two and three species. The high co-occurrence of Aspergilli in this has been suggested to increase the chances of mycotoxin contamination. The high co-occurrence of Aspergilli was also reported on chili samples from Taif City, Saudia Arabia [16], whereas the co-occurrence of Aspergilli in sample chili from Spain was $35.5 \%$ [30].

\subsection{Molecular Detection of Mycotoxin Production Genes}

In order to investigate the potential of AF and OTA production, two isolates of $A$. flavus and one isolate of each stain of $A$. parasiticus, A. japonicus, A. carbonarius, and A. niger isolated from the chili samples were examined by PCR. The PCR was used for the detection of aflatoxigenic Aspergilli based on the intermediated enzymes, including the norsolorinic acid reductase-encoding gene nor-1, the sterigmatocystin O-methyltransferase encoding gene omt1 and the regulatory gene aflR [31]. Nor-1 gene plays a role at the beginning of AF biosynthesis by converting norsolorinic acid into averantin [32]. The aflR gene plays an essential role in the AF biosynthetic pathway by regulating the activity of other structural genes such as omt- $A$, ver- 1 and nor- $1[33,34]$. The omt $B$ gene plays a role at the end of AF biosynthesis by producing $\mathrm{O}$-methyltransferase, which converts dimethylsterigmatocystin into sterigmatocystin, which will be further transformed into $\mathrm{AFB}_{1}$.

Table 4 showed that the nor- 1 gene was detected in $A$. niger isolate, 2 A. flavus isolates, and A. parasiticus. A targeted gene of aflR was detected on all isolates, whereas DNA fragments corresponded to omt $B$ gene were only detected on two isolates of $A$. flavus and isolate of $A$. japonicus. A complete set of the genes was only detected on two isolates of $A$. flavus. To detect the potential OTA production, the primers AnPKS and AcPKS, which are specific to amplifying the DNA of the isolates of $A$. niger and A. carbonarius, respectively, were used. The results showed that the targeted gene was present in A. carbonarius but absent in A. niger. 
Table 4. Molecular characterization of Aspergillus strains isolated from dried and powdered chili purchased from the traditional and the modern markets.

\begin{tabular}{cccccccc}
\hline No & Isolates & Species & aflR & OmtB & Nor-1 & AnPKS & AcPKS \\
\hline 2 & 2B1 & Aspergillus niger & + & - & + & - & - \\
& $11 \mathrm{G} 1$ & Aspergillus flavus & + & + & + & n.d & n.d. \\
11 & $11 \mathrm{G} 2$ & Aspergillus parasiticus & + & - & + & n.d & n.d. \\
& $11 \mathrm{~B} 1$ & Aspergillus japonicus & + & + & - & n.d & n.d. \\
12 & $12 \mathrm{~B} 1$ & Aspergillus carbonarius & + & - & - & - & + \\
15 & 15G5 & Aspergillus flavus & + & + & + & n.d & n.d. \\
\hline
\end{tabular}

n.d. $=$ not determined.

It has been suggested that AF biosynthesis is a complex pathway involving the pattern of positive-and negative-acting transcriptional regulatory factors affected by environmental and nutritional parameters $[35,36]$. Thus, AF production does not only depend on the presence of the gene involved in AFs production but also the environmental condition that favors the production of AFs. Thus, to confirm the occurrence of AFs in the chili sample, the AF concentration on the sample should be determined.

\subsection{AF and OTA Concentration on Dried Chili and Chili Powder}

To investigate the AF and OTA contamination on dried chili, six samples were randomly selected and examined using HPLC. The results showed that two samples were not contaminated by AFs and OTA, one sample was only contaminated with AFs or OTA and two samples were contaminated by both AFs and OTA. The levels of the AFs $B_{1}$ and $B_{2}$ in the contaminated dried chilies were in the range of 39.3-139.5 and 2.6-33.3 $\mu \mathrm{g} / \mathrm{kg}$, whereas no $A F s G_{1}$ and $G_{2}$ were detected (Table 5). The level of OTA in contaminated chilies was in the range of $23.7-84.6 \mu \mathrm{g} / \mathrm{kg}$ (Table 5). The AFs in sample 2 might be produced by A. parasiticus (Table 3). Sample 3 was contaminated by OTA, which might be produced by A. carbonarius (Table 3). No OTA was produced in sample 2, and this corresponds to the absence of the AnPKS gene. Although A. parasiticus and A. carbonarius (Table 3) were found in sample 6, no AF or OTA was produced. Similarly, no AF and OTA was detected in sample 8 containing A. parasiticus and A. japonicus (Table 3 ). This might be explained by the environmental and nutrition conditions that do not favor the production of AFs and OTA in this sample. Sample 12 was contaminated by OTA, which might be produced by A. carbonarius as it contained the AcPKS gene.

Table 5. AF concentration on dried chili and chili powder.

\begin{tabular}{ccccc}
\hline \multirow{2}{*}{ Sample } & \multicolumn{3}{c}{ AFs $(\mu \mathrm{g} / \mathbf{k g})$} & \multirow{2}{*}{ OTA $(\mu \mathrm{g} / \mathbf{k g})$} \\
\cline { 2 - 4 } & $\mathbf{B}_{\mathbf{1}}$ & $\mathbf{B}_{\mathbf{2}}$ & $\mathbf{G}_{\mathbf{1}}+\mathbf{G}_{\mathbf{2}}$ & \\
\hline 2 & $139.5 \pm 0.7$ & $12.8 \pm 0.5$ & n.d. & n.d. \\
3 & n.d. & n.d. & n.d. & $26.3 \pm 0.7$ \\
6 & n.d. & n.d. & n.d. & n.d. \\
8 & n.d. & n.d. & n.d. & n.d. \\
12 & $39.3 \pm 0.7$ & $2.6 \pm 0.5$ & n.d. & $23.7 \pm 0.7$ \\
15 & $100.1 \pm 0.7$ & $33.3 \pm 0.5$ & n.d. & $84.6 \pm 0.7$ \\
\hline \multicolumn{5}{c}{${ }^{*}$ n.d. $=$ not detected. }
\end{tabular}

Interestingly, AFs were also found in sample 12, which was not expected. This might be produced from Aspergillus flavi, which might also contaminate the sample. A high amount of AF was found in sample 15, which was expected, as A. flavus showed the complete set of the genes, and sample 15 contained four instances of $A$. flavus and one of A. parasiticus (Table 3). Interestingly, OTA was also found in this sample. This indicates that the sample might also be contaminated by OTA-producing fungi. The co-occurrence of different mycotoxins in one product raises the chance of synergetic interaction, which might result in more adverse impacts on human health [37]. The results showed that some of the dried chilies were contaminated by AFs and OTA simultaneously. This might lead to 
a possibly higher risk for adverse health effects, as demonstrated by the fact that OTA can raise the mutagenicity of $\mathrm{AFB}_{1}$ once they have infected the same substrate.

\section{Discussion}

\section{Is Indonesian Chili more Contaminated than in Other Countries?}

Chili is the second largest commodity after black pepper, contributing to $16 \%$ of the world spice trade [12]. The global production of chili and pepper crops comes to around 32 million tons, which are cultivated on approximately 1.9 million ha of land [17]. Chilis have been reported to be one of the commodities with the highest AF contamination [38]. In this work, 15 samples of dried chili, including eight samples from a traditional market and seven of the most consumed trademarks available in the modern markets, were examined for their microbiota, the occurrence of potential mycotoxigenic fungi, the molecular detection of potential mycotoxin producing isolate and mycotoxins level in the samples.

The levels of AF and OTA contamination in Indonesian dried chili obtained in this study were in the range of those reported from previous studies [12-16,39]. Contamination levels of AFs $B_{1}$ on the whole and ground chilies from Pakistan were $0-96.3 \mu \mathrm{g} / \mathrm{kg}$ and $0-89.56 \mu \mathrm{g} / \mathrm{kg}$, respectively [12]. Set and Erkmen [11] reported that 120 samples of ground red chili peppers sold in Gaziantep, Turkey were found to be contaminated with total $A F s$ and $A F s B_{1}$, in which the number of samples containing AFs $B_{1}$ over the legal limit in Turkey was higher in unpacked $(62.5 \%)$ than that of packed ground red chili $(9.4 \%)$. Jalili and Jinap reported that $65 \%$ of chili purchased from modern markets and traditional markets in Malaysia were contaminated by AFs, with total AFs level in the range of $0.2-79.7 \mu \mathrm{g} / \mathrm{kg}$ [13]. They also reported that $81.25 \%$ of the samples contained OTA in the range of $0.2-101.2 \mu \mathrm{g} / \mathrm{kg}$. Roy et al. reported that AFs $B_{1}$ was found in red chili taken from 3 cities in Bangladesh with AFs level > $20 \mu \mathrm{g} / \mathrm{kg}$ [14]. A combination of morphological, physiological, and molecular detection showed that chili imported to Qatar contained AFs $B_{1}, B_{2}$, and total AFs of $69.28,1.73$, and $71.1 \mu \mathrm{g} / \mathrm{kg}$ sample [15]. Gherbawy et al. analyzed the chili samples from Taif City, Saudia Arabia, and found that the chili powder was contaminated with AFs in the range of 20-170 $\mu \mathrm{g} / \mathrm{kg}$ and 35-200 $\mu \mathrm{g} / \mathrm{kg}$ for crushed and powdered chili, respectively [16]. Khan et al. reported that AFs contamination in whole, crushed, and powdered chili collected from all over Pakistan were 11.7, 27.8, and $31.2 \mu \mathrm{g} / \mathrm{kg}$, respectively [39].

Many countries have established regulations for mycotoxin contamination in food due to its adverse effect on human health. Some countries have established a legal limit for both $\mathrm{AFB}_{1}$ and $\mathrm{AFs}$ for all foods. The maximum limits for $\mathrm{AFB}_{1}$ vary from $2 \mu \mathrm{g} / \mathrm{kg}$ in Tunisia to $20 \mu \mathrm{g} / \mathrm{kg}$ in Nigeria, and the limits for total AFs vary from $5 \mu \mathrm{g} / \mathrm{kg}$ in Cuba to $35 \mu \mathrm{g} / \mathrm{kg}$ in Malaysia. In the United States, the maximum level of $\mathrm{AFB}_{1}$ contamination permitted in human food is $20 \mu \mathrm{g} / \mathrm{kg}$ [40]. On the other hand, some countries have established a legal limit for certain products. For instance, Turkey and Europe set the legal limits of AFs in ground red chili pepper for total $\mathrm{AFB}_{1}$ and total AFS of 5 and $10 \mu \mathrm{g} / \mathrm{kg}$, respectively [41,42]. In Korea, the maximum limit for ground red pepper of total $\mathrm{AFB}_{1}$, total $\mathrm{AFs}_{\text {, and }}$ OTA were 10, 15, and $7 \mathrm{ng} / \mathrm{g}$ [28]. In Indonesia, the legal limit for $\mathrm{AFB}_{1}, \mathrm{AFs}$, and OTA on chili has not yet established. However, a limit of $20 \mu \mathrm{g} / \mathrm{kg}$ for total AFs is allowed for the category "coconut, spices, and open drug medicines/herbs". The result of the current study showed that the AF contaminations for some samples were higher than the legal limit.

The result of this preliminary study showed that Indonesian chili has high a risk of AF contamination; thus, attempts should be made to prevent or lower the mycotoxin contamination, such as by using the method suggested by Set and Erkmen [11] including applying good agricultural practice and the prevention of soil contact during harvesting; transporting in clean containers; applying good personnel hygiene, as well as the removal of damaged peppers, hulls, leaves, and garbage during sorting; applying Good Manufacturing Processes during washing, seed removal and grinding; prevention of cross-contamination, drying to up to $10 \%-12 \%$ moisture content at $70-100{ }^{\circ} \mathrm{C}$ for $1-3 \mathrm{~h}$ in a dryer for the drying process; and applying vacuum packaging and storage under an air conditioner 
(below 65\% RH and $20^{\circ} \mathrm{C}$ ). In addition, Duman suggested that storage in hermetic cubs lowers the risk of AF contamination [43].

\section{Conclusions}

In this study, the potential mycotoxin contamination of dried Indonesian chili was assayed using a combination of morphological, molecular detection, and chromatography techniques. The result of the morphological assays showed that Aspergillus spp. was the dominant fungi contaminating the chili, and the commonly found isolates were A. flavus and A. parasiticus, which are known to be AF producers. Molecular detection by PCR showed that several genes involved in AF and OTA biosynthesis were found in several isolates. In addition, some of the dried chilies were contaminated by AFs and OTA. The results of this study showed the potential risk of dried chili being contaminated by aflatoxigenic and ochratoxigenic fungi as well as AFs and OTA, and thus it is highly advisable to control the proper harvesting, drying, handling, storage, and transportation conditions to reduce this contamination.

Author Contributions: R.W. conceptualized, supervised and wrote the original draft, E.S.R. and M.J.T. supervised the study team and their data collection, I.C.M. and M.D.P.S. conducted the formal analysis of quantitative and qualitative data, E.S.R. acquired funding; W.S. and F.A.P. advised on statistical analysis; E.S.R., W.S. and M.J.T. contributed to the review and editing of the manuscript. All of the authors read and approved the final manuscript. All authors have read and agreed to the published version of the manuscript.

Funding: This research was partly funded by the Ministry of Research, Technology and Higher Education of Indonesia through the World Class Professor (WCP) Program [contract number 123.10/D2.3/KP/2018].

Acknowledgments: We express our gratitude to the Ministry of Research, Technology and Higher Education of Indonesia through the World Class Professor (WCP) Program for the partial funding and the Center for Food and Nutrition Studies for their technical support.

Conflicts of Interest: The authors declare no conflict of interest.

\section{References}

1. Eurostat. Available online: https://ec.europa.eu/eurostat (accessed on 10 September 2018).

2. Rapid Alert System for Food and Feed. Available online: https://webgate.ec.europa.eu/rasff-window/portal/ ?event=searchForm\&cleanSearch=1 (accessed on 10 September 2018).

3. Eaton, D.L.; Gallagher, E.P. Mechanisms of Aflatoxin Carcinogenesis. Annu. Rev. Pharmacol. Toxicol. 1994, 34, 135-172. [CrossRef] [PubMed]

4. Sweeney, M.J.; Dobson, A.D.W. Mycotoxin production by Aspergillus, Fusarium and Penicilliium species. Int. J. Food Microbiol. 1998, 43, 141-158. [CrossRef]

5. International Agency for Research on Cancer. Some Naturally Occurring Substances, Food Items and Constituents, Heterocyclic Aromatic Amines and Mycotoxins. In Proceedings of the IARC Monographs on the Evaluation of the Carcinogenic Risk of Chemicals to Humans, Lyon, France, 9-16 June 1992.

6. Bellí, N.; Ramos, A.J.; Sanchis, V.; Marín, S. Incubation time and water activity effects on ochratoxin a production by Aspergillus section Nigri strains isolated from grapes. Lett. Appl. Microbiol. 2004, 38, 72-77. [CrossRef] [PubMed]

7. Ikoma, T.; Tsuchiya, Y.; Asai, T.; Okano, K.; Ito, N.; Endoh, K.; Yamamoto, M.; Nakamura, K. Ochratoxin A contamination of red chili peppers from Chile, Bolivia and Peru, countries with a high incidence of gallbladder cancer. Asian Pac. J. Cancer Prev. 2015, 16, 5987-5991. [CrossRef] [PubMed]

8. European Commission Opinion of the Scientific Committee on Food on Ochratoxin A (Expressed on 17 September 1998). Available online: https://ec.europa.eu/food/sites/food/files/safety/docs/sci-com_scf_out14 _en.pdf (accessed on 10 September 2017).

9. Wagacha, J.M.; Muthomi, J.W. Mycotoxin problem in Africa: Current status, implications to food safety and health and possible management strategies. Int. J. Food Microbiol. 2008, 124, 1-12. [CrossRef]

10. Bhat, R.V.; Vasanthi, S. Food Safety in Food Security and Food Trade, Mycotoxin Food Safety Risk in Developing Countries. Int. Food Policy Res. Institute Br. 2003, 10, 3-17. [CrossRef]

11. Set, E.; Erkmen, O. Occurrence of aflatoxins in ground red chili pepper and pistachio nut. Int. J. Food Prop. 2014, 17, 2322-2331. [CrossRef] 
12. Iqbal, S.Z.; Paterson, R.R.M.; Bhatti, I.A.; Asi, M.R.; Sheikh, M.A.; Bhatti, H.N. Aflatoxin B1in chilies from the Punjab region, Pakistan. Mycotoxin Res. 2010, 26, 205-209. [CrossRef]

13. Jalili, M.; Jinap, S. Natural occurrence of aflatoxins and ochratoxin A in commercial dried chili. Food Control 2012, 24, 160-164. [CrossRef]

14. Roy, M.; Harris, J.; Afreen, S.; Deak, E.; Gade, L.; Balajee, S.A.; Park, B.; Chiller, T.; Luby, S. Aflatoxin contamination in food commodities in Bangladesh. Food Addit. Contam. Part B 2013, 6, 17-23. [CrossRef]

15. Hammami, W.; Fiori, S.; Al Thani, R.; Ali Kali, N.; Balmas, V.; Migheli, Q.; Jaoua, S. Fungal and aflatoxin contamination of marketed spices. Food Control 2014, 37, 177-181. [CrossRef]

16. Gherbawy, Y.A.; Shebany, Y.M.; Hussein, M.A.; Maghraby, T.A. Molecular detection of mycobiota and aflatoxin contamination of chili. Arch. Biol. Sci. 2015, 67, 223-234. [CrossRef]

17. Food and Agriculture Organization. Available online: http://www.faostat.org/ (accessed on 5 May 2017).

18. Rahayu, E.S.; Sardjono, S.; Samson, R.A. Jamur Benang (Mold) Pada Bahan Pangan; PT Kanisius: Yogyakarta, Indonesia, 2014.

19. Samson, R.; Houbraken, J.; Thrane, U.; Frisvad, J.C.; Andersen, B. Food and Indoor Fungi; CBS-KNAW Fungal Biodiversity Centre: Utrecht, The Netherlands, 2010.

20. Klich, M.A.; Pit, J.I. A Laboratory Guide to Common Aspergillus Species and Teir Teleomorphs; CSIRO Division of Food Science and Technology, North Ryde: Sydney, NSW, Australia, 1988.

21. Samson, R.; Hoekstra, E.; Frisvad, J.C.; Filtenborg, O. Introduction to Food and Airborne Fungi, 7th ed.; Centraalbureau voor Schimmelcultures: Utrecht, The Netherlands, 2004.

22. Mohana, D.C.; Thippeswamy, S.; Abhishek, R.U.; Shobha, B.; Mamatha, M.G. Studies on seed-borne mycoflora and aflatoxin B1 contaminations in food based seed samples: Molecular detection of mycotoxigenic Aspergillus flavus and their management. Int. Food Res. J. 2016, 23, 2689-2694.

23. Geisen, R. Multiplex Polymerase Chain Reaction for the Detection of Potential Aflatoxin and Sterigmatocystin Producing Fungi. Syst. Appl. Microbiol. 1996, 19, 388-392. [CrossRef]

24. Scherm, B.; Palomba, M.; Serra, D.; Marcello, A.; Migheli, Q. Detection of transcripts of aflatoxin genes aflD, $\mathrm{aflO}$, and aflP by reverse transcription-polymerase chain reaction allows differentiation of aflatoxin-producing and non- producing isolates of Aspergillus flavus and Aspergillus parasiticus. Int. J. Food Microbiol. 2005, 98, 201-210. [CrossRef]

25. Bokhari, F.M. Spices Mycobiota and Mycotoxins Available in Saudi Arabia and Their Abilities to Inhibit Growth of Some Toxigenic Fungi. Mycobiology 2007, 35, 47. [CrossRef]

26. Santos, L.; Marín, S.; Mateo, E.M.; Gil-Serna, J.; Valle-Algarra, F.M.; Patiño, B.; Ramos, A.J. Mycobiota and co-occurrence of mycotoxins in Capsicum powder. Int. J. Food Microbiol. 2011, 151, 270-276. [CrossRef]

27. Salari, R.; Najafi, M.B.H.; Boroushaki, M.T.; Mortazavi, S.A.; Najafi, M.F. Assessment of the microbiological quality and mycotoxin contamination of iranian red pepper spice. J. Agric. Sci. Technol. 2012, 14, 1511-1521.

28. Ham, H.; Kim, S.; Kim, M.H.; Lee, S.; Hong, S.K.; Ryu, J.G.; Lee, T. Mycobiota of ground red pepper and their aflatoxigenic potential. J. Microbiol. 2016, 54, 832-837. [CrossRef]

29. Mandeel, Q.A. Fungal contamination of some imported spices. Mycopathologia 2005, 159, 291-298. [CrossRef]

30. Sardiñas, N.; Gil-Serna, J.; Santos, L.; Ramos, A.J.; González-Jaén, M.T.; Patiño, B.; Vázquez, C. Detection of potentially mycotoxigenic Aspergillus species in Capsicum powder by a highly sensitive PCR-based detection method. Food Control 2011, 22, 1363-1366. [CrossRef]

31. Yu, J.; Cleveland, T.E. Aspergillus flavus Genomics for Discovering Genes Involved in Aflatoxin Biosynthesis. In Polyketides; ACS Symposium Series; American Chemical Society: Washington, DC, USA, 2007; Volume 955, pp. 17-246. ISBN 0-8412-3978-9.

32. Tami, M.D.; Hammond, T.; Noordermee, D.; Zhang, Y.Q.; Keller, N. The Sterigmatocystin Cluster Revisited: Lesson from a Genetic Model. In Aflatoxin and Safety; CRC Press: New York, NY, USA, 2005.

33. Woloshuk, C.P.; Foutz, K.R.; Brewer, J.F.; Bhatnagar, D.; Cleveland, T.E.; Payne, G.A. Molecular characterization of aflR, a regulatory locus for aflatoxin biosynthesis. Appl. Environ. Microbiol. 1994, 60, 2408-2414. [CrossRef] [PubMed]

34. Chang, P.K.; Yu, J.; Bhatnagar, D.; Cleveland, T.E. Repressor-AFLR interaction modulates aflatoxin biosynthesis in Aspergillus parasiticus. Mycopathologia 1999, 147, 105-112. [CrossRef] [PubMed]

35. Liu, Y.; Xu, H.-L.; Show, K.-Y.; Tay, J.-H. Anaerobic granulation technology for wastewater treatment. World J. Microbiol. Biotechnol. 2002, 18, 99-113. [CrossRef] 
36. Diao, E.; Dong, H.; Hou, H.; Zhang, Z.; Ji, N.; Ma, W. Factors influencing aflatoxin contamination in before and after harvest peanuts: A review. J. Food Res. 2015, 4, 148-154. [CrossRef]

37. Alborch, L.; Bragulat, M.R.; Castellá, G.; Abarca, M.L.; Cabañes, F.J. Mycobiota and mycotoxin contamination of maize flours and popcorn kernels for human consumption commercialized in Spain. Food Microbiol. 2012, 32, 97-103. [CrossRef]

38. Marín, S.; Colom, C.; Sanchis, V.; Ramos, A.J. Modelling of growth of aflatoxigenic A. flavus isolates from red chilli powder as a function of water availability. Int. J. Food Microbiol. 2009, 128, 491-496. [CrossRef]

39. Khan, M.A.; Asghar, M.A.; Iqbal, J.; Ahmed, A.; Shamsuddin, Z.A. Aflatoxins contamination and prevention in red chillies (Capsicum annuum L.) in Pakistan. Food Addit. Contam. Part B 2014, 7, 1-6. [CrossRef]

40. United States Food and Drug Administration Guidance for Industry: Action Levels for Poisonous or Deleterious Substances in Human Food and Animal Feed. Available online: https://www.fda.gov/food/guidanceregulation/guidancedocumentsregulatoryinformation/chemica lcontaminantsmetalsnaturaltoxinspesticides/ucm077969.htm (accessed on 15 May 2017).

41. Turkish Food Codex. Regulation No. 2011/28157, the Maximum Allowed Level of Food Contaminants; Official Gazette of Publication: Ankara, Turkey, 2011.

42. European Commission (EC). Regulation No: 165/2010 of 26 February 2010 setting maximum levels for certain contaminants in foodstuffs. Official Journal of the European Union 2010, L 50/8-12.

43. Duman, A.D. Storage of red chili pepper under hermetically sealed or vacuum conditions for preservation of its quality and prevention of mycotoxin occurrence. J. Stored Prod. Res. 2010, 46, 155-160. [CrossRef]

(C) 2020 by the authors. Licensee MDPI, Basel, Switzerland. This article is an open access article distributed under the terms and conditions of the Creative Commons Attribution (CC BY) license (http://creativecommons.org/licenses/by/4.0/). 